\title{
Functions of state-owned corporations in the structure of the public sector of the Russian Federation
}

\author{
Tatiana Arkhipova $^{1 \text { a }}$, Artem Dibrov $^{2}$, Ludmila Beskrovnaya $^{2}$ and Alexandra Shchukina ${ }^{2}$ \\ ${ }^{1}$ National Research Tomsk Polytechnic University, Lenin Avenue 30, Tomsk 634050, Russia \\ Tomsk State University of Control Systems and Radioelectronics, Lenin Avenue 40, Tomsk 634050, Russia \\ ${ }^{2}$ National Research Tomsk Polytechnic University, Lenin Avenue 30, Tomsk 634050, Russia
}

\begin{abstract}
There are many different types of economic systems used through the world. The government attempts to control and regulate economic branches of strategic importance. Property is a fundamental element of economic power, it is a basis required to fulfill the state functions and tasks, to provide society with vital benefits such as health care, education, high living standard, life quality and well-being of citizens. A major part of production of public goods is carried out by the public sector of the country. Stateowned corporations in Russia are relatively new business structures. They have a market leading position to deal with global economic and social problems of the state.
\end{abstract}

\section{Introduction}

The harmonious development of modern economic systems is based on complex collective interactions. This inevitably raises the question of whether there are coordination mechanisms for such interactions. The answer to this question has been searched since the time of classical political economy. Modern science does not give a clear answer as well. In modern society the state acts as a strategic coordinator of activity of other market entities, it supports positive structural and institutional economic reforms to achieve the objectives of the society, to increase public ownership.

\section{The place of state-owned corporations in the structure of public sector}

State ownership is the basis for the implementation of state regulations in the national economy. Therefore, the higher the percentage of state-owned property is, the more powerful and stronger the state is and it can greatly affect the economy of the country as a whole. A public sector is a part of the state property and is mainly characterized as a collection of corporations and enterprises owned by the state, which operate under the direct control of the state.

According to the official statistics of the Federal State Statistics service, we can draw the conclusion that the share of state enterprises decreased from 2.4 to $2.2 \%$ in the period from 2012 to 2015 [1].

\footnotetext{
$\overline{{ }^{a} \text { Corresponding author: bond1110 } @ y a n d e x . r u ~}$
}

There is a trend towards further transformation of state enterprises into other forms of ownership. This is considered to be due to the fact that belonging to the state the property requires the expenditure of large sums of money and considerable resources from the state budget of the Russian Federation. Therefore, the government transfers a part of state property into private property to reduce the financial burden of society.

There are at least five important sectors of Russian economy in which state-owned enterprises dominate: infrastructure (railway transport, pipes, nuclear energy), mining (oil and gas, diamonds), military industrial complex, financial services (banking, insurance, pension funds) and media [2].

Analyzing the presence of the state in Russian economy, as a producer of goods and services, and taking into consideration the data of monitoring, which was carried out by the Federal State Statistics service, we can confirm the increase in the ratio of the totals of production and economic activities of the state in spite of the fact that the ratio of public sector did not exceed 15$25 \%$ for most indices except investment and employment (data are shown in the table below).

Table 1. A percentage share of the public sector for different indices in $2011-2014$ [3]

\begin{tabular}{|c|l|l|l|l|}
\hline Index & $\mathbf{2 0 1 1}$ & $\mathbf{2 0 1 2}$ & $\mathbf{2 0 1 3}$ & $\begin{array}{c}\text { The 1 } \\
\text { half year } \\
\text { of } \\
\mathbf{2 0 1 4}\end{array}$ \\
\hline $\begin{array}{l}\text { The volume } \\
\text { of shipped }\end{array}$ & 67,1 & 68,6 & 80,7 & 76,6 \\
\hline
\end{tabular}




\begin{tabular}{|c|c|c|c|c|}
\hline $\begin{array}{l}\text { goods from } \\
\text { own } \\
\text { production, } \\
\text { completed } \\
\text { works and } \\
\text { provided } \\
\text { services }\end{array}$ & & & & \\
\hline $\begin{array}{l}\text { Passenger } \\
\text { turnover of } \\
\text { transport } \\
\text { organizations }\end{array}$ & 65,3 & 64,5 & 62,7 & 60,4 \\
\hline $\begin{array}{l}\text { Commercial } \\
\text { freight } \\
\text { turnover } \\
\text { (shipments } \\
\text { carried out } \\
\text { by transport } \\
\text { organizations } \\
\text { (without the } \\
\text { organizations } \\
\text { of pipeline } \\
\text { transportatio } \\
\text { n)) }\end{array}$ & 36,4 & 92,9 & 93,4 & 94,6 \\
\hline $\begin{array}{l}\text { Communicati } \\
\text { on services }\end{array}$ & 13,4 & 14,2 & 13,7 & 13,2 \\
\hline $\begin{array}{l}\text { Internal costs } \\
\text { on research } \\
\text { and } \\
\text { development }\end{array}$ & 73,8 & 75,4 & 74,1 & 70,8 \\
\hline $\begin{array}{l}\text { Investment } \\
\text { into capital } \\
\text { stock at the } \\
\text { expense of } \\
\text { all sources of } \\
\text { funding }\end{array}$ & $\begin{array}{l}28,8 / 2 \\
1,3\end{array}$ & $\begin{array}{l}28,8 / 2 \\
0,9\end{array}$ & $\begin{array}{l}30,3 / 2 \\
1,0\end{array}$ & $\begin{array}{l}25,6 / \\
19,2\end{array}$ \\
\hline $\begin{array}{l}\text { Average } \\
\text { number } \\
\text { workers }\end{array}$ & 24,9 & 25,8 & 26,7 & 28,0 \\
\hline
\end{tabular}

Having a closer look at the scale of the public sector we can measure the limits of state presence and intervention in national economy. At the same time, regardless of the type of the economic system, functions performed by the state do not differ.

P. Samuelson identified and described four basic functions of the state, or "four types of state activity": direct control, public consumption, state production and social service costs [4]. The state carries out functions imposed on it through the public sector.

We believe that the structure of the public sector can be presented depending on the purposes of organizations for which they have been set up (see the fig. 1).

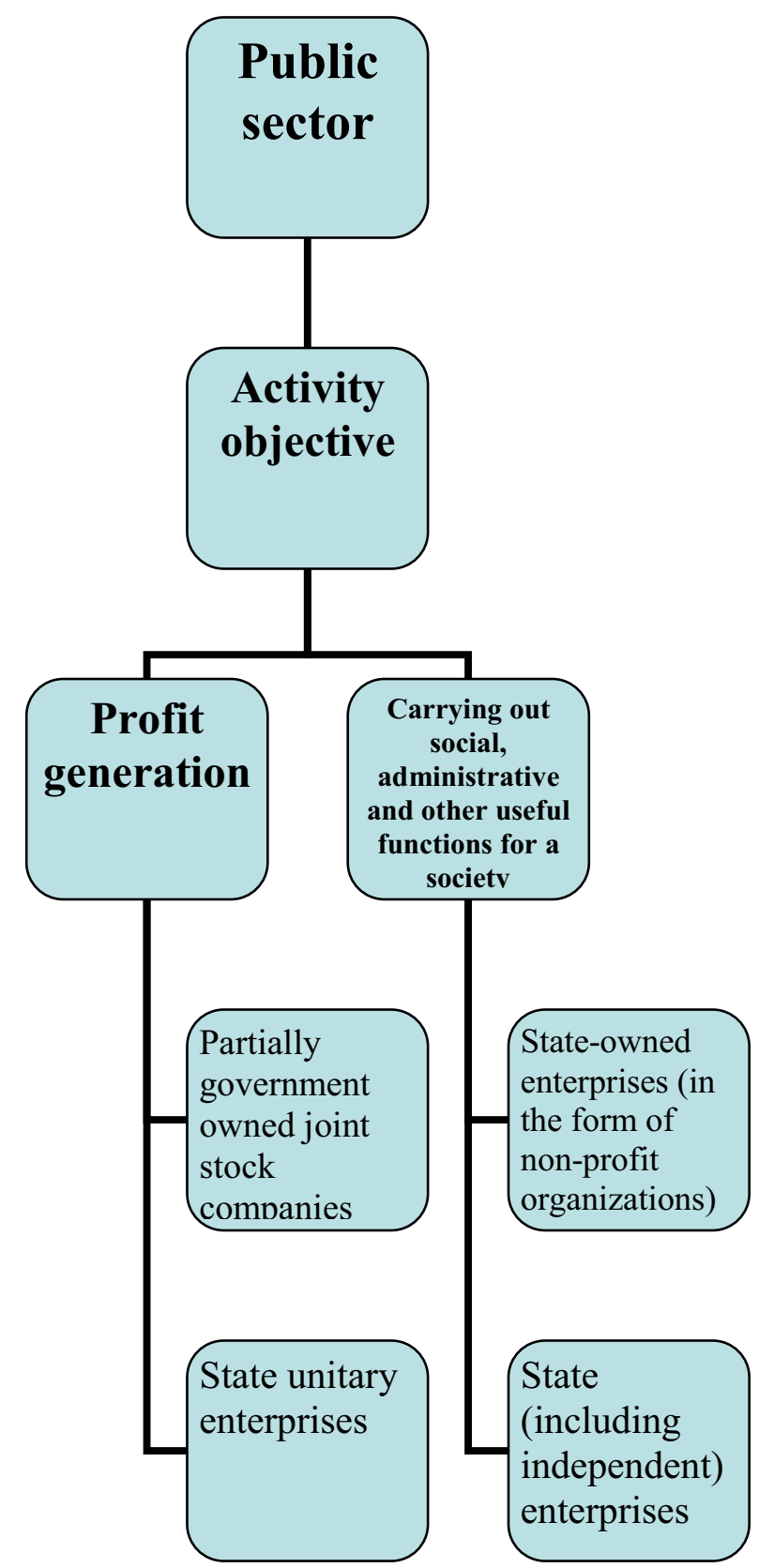

Fig. 1. An organizational structure of the public sector in accord with the objectives of establishing various economic entities

The place of state-owned corporations in the structure of the public sector operation can be revealed through the analysis of functioning of state-owned corporations.

Firstly, we shall define what does the concept of "state-owned corporation" stand for. The word combination "state-owned corporation" has economic sense - it is a corporation owned by the state. In English, the term «State-owned corporation» is used and it means government owned joint stock company. References to a large number of foreign state-owned corporations in papers are right if we define a state-owned corporation as a "joint stock company" [5]. Thus, a foreign stateowned corporation is a legal entity that is created by the government in order to partake in commercial activities on the government's behalf. A state-owned enterprise can 
be either wholly or partially owned by a government and is typically earmarked to participate in commercial activities.

A Russian state-owned corporation is a type of a nonprofit organization. In accordance with the Federal Law "On Non-profit Organizations" the "state corporation" is a non-commercial organization without membership founded by the Russian Federation on the basis of a property contribution, established to pursue social, managerial and other functions of public use [6].

Consequently, the corporation is founded by the Russian Federation on the basis of a property contribution and the assets handed over to the state corporation by the Russian Federation shall be property of the state corporation. Almost all state-owned corporations were founded on the basis of property contribution of the Russian Federation. However, the structure of property contribution is different for each state-owned enterprise.

The distinguishing features of state-owned corporations are:

1. The corporation is set up to pursue social, managerial and other functions of public use.

2. The corporation as a form of non-profit organization is one not having profit-making as the main objective of its activity.

3. The state corporation may pursue entrepreneurial activity only insofar as it serves the attainment of the goals for which it has been set up and insofar as it complies with these goals.

4. The provisions of the law "On non-profit organizations" may not be applied to the state corporation except as otherwise provided in the law whereby the state corporation is formed.

5. To set up a state corporation no constituent documents shall be needed as required by Article 52 of the Civil Code of the Russian Federation [7].

6. The state corporation shall be set up under a federal law.

\section{Classification corporations}

of

state-owned

The corporation is founded by the Russian Federation on the basis of a property contribution. The property, which is given to the state corporation, is the property of the state corporation [6, Article 7.1].

As it follows from the regulatory legal act, the state formally waives the rights of the owner, alienating the resources of the state corporation. State corporations can be differentiated in accord with goals, objectives and functions for which they have been set up, as well as in accord with the managerial status and participation of the state in the authorized capital.

The organizational-legal form of the state-owned corporation was chosen largely because it provided greater flexibility in the utilization of financial resources and simplified (accelerated) the processes of restructuring and consolidating state property in particular sections of the economy [8]:
State-owned corporations can be split up into two groups in accord with the goals for which they have been set up and the methods of goals' attainment [9]:

-Funds. They subsidize special purpose types of activity recognized as socially significant or invest money in the long-term budgetary target projects: National Bank for Development, Support fund for the reform of the housing and utilities sector, Olympstroy, RUSNANO;

-Industrial holdings. They are manufacturers and they should contribute to the modernizations of similar branches and perform well in the global market: Russian Technologies, ROSATOM.

Having generalized activity goals, objectives, functions for which they have been set up and resources provided, we can offer a new typology of state-owned corporations:

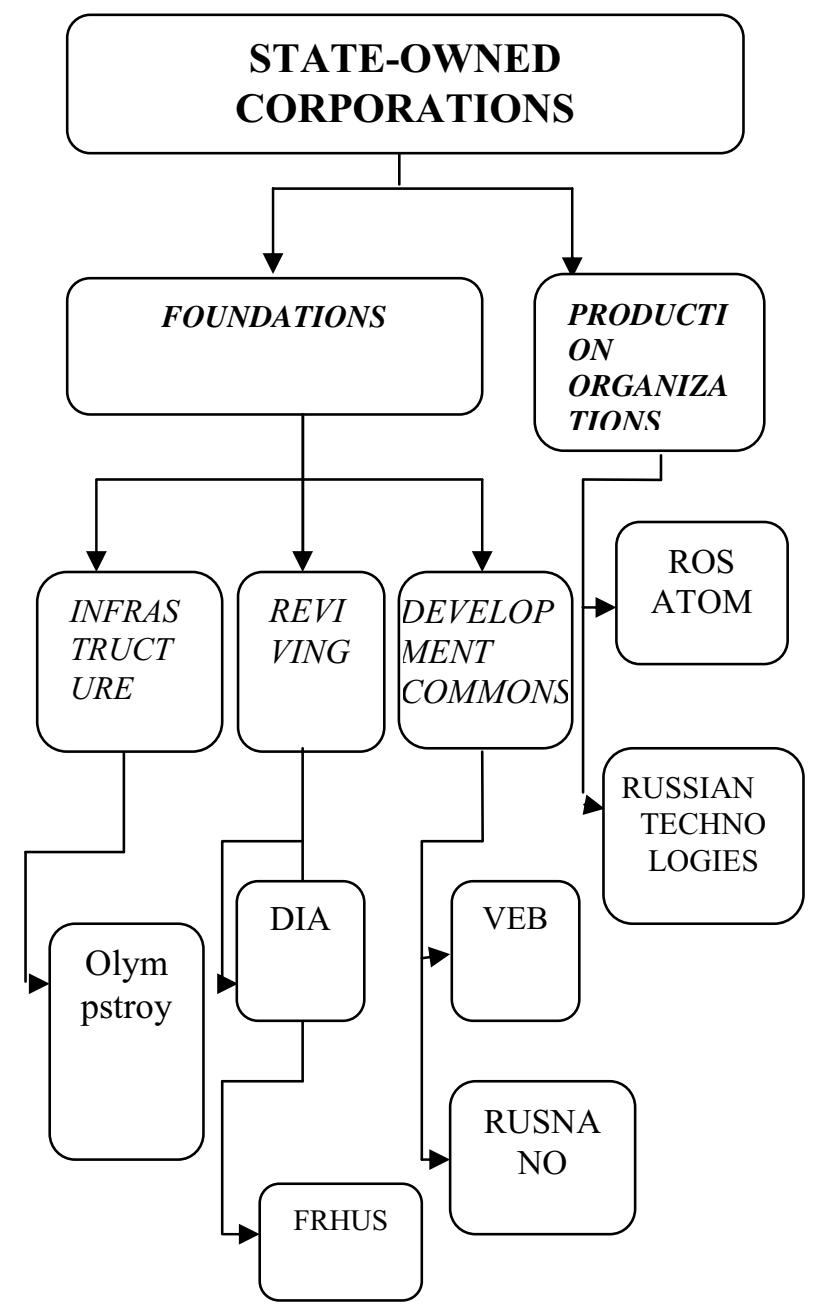

Fig. 1. Typology of state-owned corporations

As shown in fig. 2, state-owned corporations are differentiated in accord with business activities and functions they carry out. For instance, the state-owned corporation "Olympstroy" was engaged in design, development, construction and maintenance of Olympic venues in Sochi. The company's program on construction of Olympic venues included Olympic sport venues, a biathlon complex, a ski complex etc. Having 
achieved its primary objective within a short period of time, the company was dissolved. It is difficult to overestimate the activity of the state-owned corporation "Deposit insurance agency (DIA)" which ensures operations of the deposit insurance system. The Agency's mission is to effectively protect rights and legitimate interests of depositors and other creditors of problem and insolvent Russian banks, encourage credit organizations to conduct responsible business operations, as well as contribute to maintaining stability of the banking system of the Russian Federation. Priority goals and objectives of the Agency include enhancement of stability of the Russian banking system and protection of bank creditors and insured pension funds' customers. [10]. The state-owned corporation "Support fund for the reform of the housing and utilities sector (FRHUS)" stimulates formation of effective mechanisms for management of housing properties and implementation of resource-saving technologies [11]. The state-owned corporation "VEB", National Bank for Development, facilitates implementation of public social and economic policy implementation and improvement of competitiveness of the national economy and its modernization through innovation [12]. The state-owned corporation "RUSNANO" implements state policy for the development of the nanoindustry in Russia, acting as a co-investor in nanotechnology projects, which have substantial economic or social potential [13]. The stateowned corporation ROSATOM operates in the civilian and defense sectors. It works on a global scale to provide comprehensive nuclear services that range from uranium enrichment to nuclear waste treatment. ROSATOM is a proponent of the uniform national policy and best management practices in nuclear power utilization, the nuclear weapons industry, and nuclear safety. ROSATOM is responsible for meeting Russia's international commitments regarding peaceful uses of nuclear energy and nuclear non-proliferation [14]. The state-owned corporation "Russian Technologies" was established to contribute to the development, production and export of high-tech industrial products [15].

\section{Conclusion}

The combination of Western sanctions and tumbling oil prices is pushing Russia deeper into recession. Russia's economy suffers recession. Thus, the activity of stateowned corporations can play an important role in Russian economy to solve economic and social problems. They have great strategic and social significance to Russia: they develop and support branches of the national economy. When state-owned corporations complete their tasks, they can be dissolved or re-organized to create a competitive environment for economic entities and to prevent monopolies and government regulation of private property.

\section{References}

1. The official website of Unified Interdepartmental Statistical Information System [Electronic resource].
- 2015. - Mode of access: http://www.fedstat.ru/indicator/data.do?id=42930

2. A. Neshchadin, O. Kuznetsov, V. Kashin Rus. Econom. Trends, 8, 3-27 (2007).

3. V. Mau. "Rossijskaya e'konomika v 2014 godu. Tendencii $i$ perspektivy» (Moscow, Gaidar Inst. publ. house, 2015).

4. P. Samuelson. Economics, 1, 155-156 (1992).

5. Horizons of industrial policy. The web site of the expert committee on industrial policy. [Electronic resource]. - 2007. - Mode of access: [http://www.prompolit.ru].

6. The Federal Law dated 12.01.1996 № 7-FZ (version of 01.12.2007).

7. Civil code of the Russian Federation (part 1) of 30.11.1994 № 51-FZ.

8. A. Radygin, Y. Simachev, R. Entov, Russian Journal of Economics. 1(1), 55-80 (2015).

9. Volkov V. "Goskorporacii: ocherednoj institucional'nyj e'ksperiment». Pro et Contra September-December (2008).

10. The official website of the state-owned enterprise "Deposit insurance agency (DIA)" [Electronic resource]. - 2015. - Mode of access: http://www.asv.org.ru/agency/

11. The official website of the state-owned enterprise "Support fund for the reform of the housing and utilities sector" [Electronic resource]. - 2015. Mode of access: http://fondgkh.ru/about/index.html

12. The official website of the state-owned enterprise "Bank for development" [Electronic resource]. 2015. - Mode of access: http://www.veb.ru/about/mission/

13. The official website of the state-owned enterprise "RUSNANO" [Electronic resource]. - 2015. Mode of access: http://www.rusnano.com/about

14. The official website of the state-owned enterprise "ROSATOM" [Electronic resource]. - 2015. Mode of access: http://www.rosatom.ru/aboutcorporation/mission/

15. The official website of the state-owned enterprise "Russian Technologies" [Electronic resource]. 2015. - Mode of access: http://www.rostec.ru/about/article/580 